\title{
Activation of Metabotropic Glutamate Receptor 1 Accelerates NMDA Receptor Trafficking
}

\author{
Jian-yu Lan, Vytenis A. Skeberdis, Teresa Jover, Xin Zheng, Michael V. L. Bennett, and R. Suzanne Zukin \\ Department of Neuroscience, Albert Einstein College of Medicine, Bronx, New York 10461
}

Regulation of neuronal NMDA receptors (NMDARs) by group I metabotropic glutamate receptors (mGluRs) is known to play a critical role in synaptic transmission. The molecular mechanisms underlying mGluR1-mediated potentiation of NMDARs are as yet unclear. The present study shows that in Xenopus oocytes expressing recombinant receptors, activation of mGluR1 potentiates NMDA channel activity by recruitment of new channels to the plasma membrane via regulated exocytosis. Activation of mGluR $1 \alpha$ induced (1) an increase in channel number times channel open probability, with no change in mean open time, unitary conductance, or reversal potential; (2) an increase in charge transfer in the presence of NMDA and the open channel blocker MK-801, indicating an increased number of functional NMDARs in the cell membrane; and (3) increased NR1 surface expression, as indicated by cell surface Western blots and immunofluorescence. Botulinum neurotoxin A or expression of a dominant negative mutant of synaptosomal associated protein of $25 \mathrm{kDa}$ molelcular mass (SNAP-25) greatly reduced mGluR $1 \alpha$-mediated potentiation, indicating that receptor trafficking occurs via a SNAP-25-mediated form of soluble $N$-ethylmaleimide sensitive fusion protein attachment protein receptor-dependent exocytosis. Because group I mGluRs are localized to the perisynaptic region in juxtaposition to synaptic NMDARs at glutamatergic synapses in the hippocampus, mGluR-mediated insertion of NMDARs may play a role in synaptic transmission and plasticity, including long-term potentiation.

Key words: metabotropic glutamate receptors; NMDA receptors; receptor trafficking; channel gating; protein kinase $C$; (1S,3R)-1-amino-cyclopentane-1,3-dicarboxylic acid; ACPD
Activation of metabotropic glutamate receptors (mGluRs) modulates NMDA receptor (NMDAR) activity and is implicated in synaptic transmission and activity-dependent synaptic plasticity (Pin and Duvoisin, 1995; Conn and Pin, 1997; Nicoletti et al., 1999). mGluRs are encoded by a gene family of eight members; further diversity is generated by alternative RNA splicing of the receptor C-terminal domains. By sequence homology, agonist selectivity, intracellular signaling mechanisms, and differential targeting in neurons, mGluRs can be divided into three classes. Group I mGluRs (mGluR1 and mGluR5) couple to diverse intracellular signaling transduction pathways. Group I mGluRs can couple positively to phospholipase $\mathrm{C}$, activation of which leads to stimulation of protein kinase $\mathrm{C}$ (PKC) and release of intracellular $\mathrm{Ca}^{2+}$ (Conn and Pin, 1997), or to adenylyl cyclase, activation of which stimulates cAMP formation (Aramori and Nakanishi, 1992; Joly et al., 1995). Group I mGluRs couple negatively to NMDARs via a G-protein-dependent, membranedelimited signaling pathway in cortical neurons (Yu et al., 1997) and depolarize CA3 neurons via a G-protein-independent, Srcdependent signaling cascade (Heuss et al., 1999).

Immunocytochemical studies reveal strikingly different distributions of group I mGluRs within the hippocampus. Although mGluR1 is localized primarily to somatostatin-positive GABAer-

Received May 21, 2001; revised May 21, 2001; accepted May 31, 2001.

This work was supported by National Institutes of Health Grants NS 20752 and NS 31282 (R.S.Z.) and NS 07512 (M.V.L.B). M.V.L.B is the Sylvia and Robert S. Olnick Professor of Neuroscience. We thank Alice P. Wang for technical support. We acknowledge the Analytical Imaging Facility of the Albert Einstein College of Medicine (Michael Cammer, director).

Correspondence should be addressed to Dr. R. Suzanne Zukin, Department of Neuroscience, Albert Einstein College of Medicine, 1300 Morris Park Avenue, Bronx, NY 10461. E-mail: zukin@aecom.yu.edu.

Copyright (C) 2001 Society for Neuroscience $\quad 0270-6474 / 01 / 216058-11 \$ 15.00 / 0$ gic interneurons, mGluR5 is highly expressed in pyramidal neurons (Shigemoto et al., 1997). At excitatory glutamatergic synapses, mGluR1 and mGluR5 are concentrated in the perisynaptic zone at the periphery of postsynaptic densities (PSDs; Baude et al., 1993; Lujan et al., 1996). Localization of group I mGluRs in close proximity to NMDARs and AMPA receptors (AMPARs), which are concentrated at PSDs, and to critical signaling proteins is consistent with a modulatory role in glutamatergic transmission.

Activation of group I mGluRs induces potentiation of NMDA EPSCs in hippocampal (Aniksztejn et al., 1992; Challiss et al., 1994), striatal (Pisani et al., 1997), and subthalamic nucleus (Awad et al., 2000) slices and potentiation of NMDA currents in lamprey motoneurons (Krieger et al., 2000) and frog spinal cord neurons (Holohean et al., 1999). However, the molecular mechanisms underlying potentiation of NMDARs by group I mGluRs are as yet unclear. Mice with null mutations of either mGluR1 (Aiba et al., 1994a,b; Conquet et al., 1994; Bordi, 1996) or mGluR5 (Lu et al., 1997) display reductions of hippocampal long-term potentiation (LTP) and abnormalities of motor coordination and associative learning. Metabotropic glutamate receptor signaling is also implicated in neurodegenerative diseases (Conn and Pin, 1997; Nicoletti et al., 1999), cortical development (Kaczmarek et al., 1997), and addiction (Wolf, 1998).

Activation of PKC induces rapid delivery of NMDARs to the cell surface of Xenopus oocytes and hippocampal neurons (Lan et al., 2001). The present study was undertaken to examine the hypothesis that potentiation of NMDARs by mGluR1 occurs at least in part by receptor trafficking. We used Xenopus oocytes to express a homogeneous population of receptors of known subtype in a geometrically simple system. Moreover, the molecular machinery for protein trafficking is highly conserved from yeast to 
mammals (Bennett and Scheller, 1993). Experiments involving patch-clamp recording, charge transfer measurements, cell surface Western blots, and immunofluorescence reveal that activation of mGluR $1 \alpha$ promotes delivery of new NMDA channels to the plasma membrane by regulated exocytosis, a mechanism that accounts entirely for potentiation of NMDAR activity. These studies provide molecular insight into synaptic function of group I mGluRs and define a novel mechanism for potentiation of NMDAR function.

\section{MATERIALS AND METHODS}

Expression constructs. Rat NMDAR subunit NR1-4b (NR1 $1_{100}$; Zukin and Bennett, 1995) cDNA was cloned in this laboratory (Durand et al., 1992); rat NR1-1a (NR1 $\left.1_{011}\right)$ and mGluR1 $\alpha$ cDNAs were gifts from Dr. S. Nakanishi (Kyoto University, Kyoto, Japan); mouse $\epsilon 1, \epsilon 2$, and $\epsilon 3$ (corresponding to rat $\mathrm{NR} 2 \mathrm{~A}, \mathrm{NR} 2 \mathrm{~B}$, and NR2C, respectively) cDNAs were gifts from Dr. M. Mishina (Niigata University, Tokyo, Japan). cDNAs were subcloned into the pBluescript SK(-) vector (Stratagene, La Jolla, $\mathrm{CA}$ ) for oocyte expression. Synaptosomal associated protein of $25 \mathrm{kDa}$ molecular mass (SNAP-25) and SNAP-25 $(\Delta 20)$ cDNAs were gifts from Dr. R. Y. Tsien (Howard Hughes Medical Institute, University of California, San Diego, CA). Capped mRNAs were synthesized as runoff transcripts from linearized plasmid cDNAs with T3 or T7 polymerase (mMessage mMachine transcription kit; Ambion, Austin, TX; $2 \mathrm{hr}$ at $37^{\circ} \mathrm{C}$ ). The concentration and integrity of mRNAs were assessed after staining with ethidium bromide by direct comparison of sample mRNAs with an RNA standard ladder (Life Technologies, Gaithersburg, MD).

Electrophysiology of recombinant NMDA receptors expressed in Xenopus oocytes. Selected stage V and VI oocytes from adult female Xenopus laevis (Xenopus I, Ann Arbor, MI) were injected with a mixture of in vitro transcribed mRNAs (20 ng of mRNA/cell; NR1:NR2:mGluR1 $\alpha$ ratio, 1:2:1) using a Nanoject injector (Drummond Scientific, Broomall, PA) as described previously (Zheng et al., 1997). Oocytes were maintained at $18^{\circ} \mathrm{C}$ in culture buffer (in mM: $103 \mathrm{NaCl}, 2.5 \mathrm{KCl}, 2 \mathrm{MgCl}_{2}, 2 \mathrm{CaCl}_{2}, 5$ HEPES, $\mathrm{pH}$ 7.5).

Whole-cell recording. Whole-cell currents were recorded from oocytes (2-6 d after injection) at ambient temperature using a GeneClamp 500 amplifier (Axon Instruments, Foster City, CA) by two-microelectrode voltage clamp, filtered at $20 \mathrm{~Hz}$, and digitized on-line at $100 \mathrm{~Hz}$ (Zheng et al., 1997). Currents were elicited by bath application of NMDA (300 $\mu \mathrm{M}$ with $10 \mu \mathrm{M}$ glycine) at a holding potential of $-60 \mathrm{mV}$. Oocytes were perfused in $\mathrm{Mg}^{2+}$-free, normal frog Ringer's solution consisting of (in mM): $116 \mathrm{NaCl}, 2.0 \mathrm{KCl}, 1.0 \mathrm{CaCl}_{2}$, and 10 HEPES, pH 7.2 (Zheng et al., 1997). Because $\mathrm{Ca}^{2+}$ influx through the NMDAR can cause $\mathrm{Ca}^{2+}$ amplification (Zheng et al., 1997), $\mathrm{Ca}^{2+}$ inactivation (Legendre et al., 1993), and activation of chloride channels endogenous to the oocyte (Leonard and Kelso, 1990) and thereby affect measurements of PKC potentiation, all experiments except those illustrated in Figures 1-3 were performed in Ringer's solution in which $\mathrm{CaCl}_{2}$ was replaced by $\mathrm{BaCl}_{2}$. The pipette resistance ranged from 0.5 to $2 \mathrm{M} \Omega$ with an internal solution consisting of (in mM): $3000 \mathrm{KCl}$ and 10 HEPES, pH 7.2. For mGluR1 $\alpha$ activation, oocytes were incubated in $(1 S, 3 R)$-1-amino-cyclopentane-1,3dicarboxylic acid (ACPD; $100 \mu \mathrm{M}, 2$ min; Sigma, St. Louis, MO) and washed. ACPD potentiation is defined as the ratio of the NMDA-elicited current measured after ACPD application to that measured before ACPD application. For direct PKC activation, oocytes were incubated in $100 \mathrm{~nm}$ 12-O-tetradecanoylphorbol 13-acetate (TPA; Sigma) for $10 \mathrm{~min}$. TPA potentiation is defined as the ratio of the NMDA-elicited current measured after TPA application to that measured before TPA application.

Single-channel recording. Single-channel currents were recorded from outside-out patches excised from devitellinized oocytes (2-7 d after injection) as described previously (Araneda et al., 1999). Pipette resistance ranged from 7 to $12 \mathrm{M} \Omega$ with an internal solution consisting of (in $\mathrm{mM}$ ): $115 \mathrm{CsCl}, 5.0 \mathrm{EGTA}$, and $10 \mathrm{HEPES}, \mathrm{pH}$ 7.2. External solutions were as described for whole-cell recording to permit direct comparisons between NMDA-elicited whole-cell and single-channel currents. NMDA (100 $\mu \mathrm{M}$ with $10 \mu \mathrm{M}$ glycine) solution was delivered to the patch from a multibarrel array fed by gravity.

Single-channel current amplitudes were determined from means of Gaussian fits to all-point amplitude histograms. The number of active channels times channel open probability $\left(n p_{\mathrm{o}}\right)$ was calculated as the total channel open time divided by recording time. Open time durations were calculated from single-channel openings above baseline but may include events from more than one channel in the same patch. All data are presented as mean \pm SEM for 4-12 experiments performed with different oocytes. Statistical significance was assessed by the Student's $t$ test (SigmaPlot 3.0) and ANOVA (CLR ANOVA 1.3).

Surface Western blot analysis. Control and ACPD-treated Xenopus oocytes expressing mGluR1 $\alpha$ and NR1-4b/NR2A receptors were screened for NMDA currents in the range of 100-300 nA and ACPD potentiation of $\sim 2-3$. Oocytes were incubated in external recording solution in the absence or presence of ACPD (100 $\mu \mathrm{M}, 2 \mathrm{~min})$ and washed twice, and surface proteins were biotinylated with the membrane-impermeant reagent sulfosuccinimidyl 2-(biotinamido) ethyl$1,3^{\prime}$-dithiopropionate (sulfo-NHS-SS-biotin, $1.5 \mathrm{mg} / \mathrm{ml}, 30 \mathrm{~min}$ at $4^{\circ} \mathrm{C}$; Pierce, Rockford, IL) according to the method of Chen et al. (1999). Cell extracts were prepared as described by Hollmann et al. (1994). To isolate biotinylated surface proteins from nonsurface proteins, cell extracts were incubated with Neutravidin-linked beads (Pierce) for $2 \mathrm{hr}$ at $4^{\circ} \mathrm{C}$, centrifuged, and washed. Bound proteins were eluted from beads by incubation with SDS-PAGE gel loading buffer containing DTT (which releases the proteins from the biotin moiety) and subjected to gel electrophoresis together with aliquots of total protein.

Cell surface immunolabeling of oocytes. Xenopus oocytes expressing NR1-4b/NR2A receptors with mGluR1 $\alpha$ were labeled with monoclonal antibody 54.1 directed to the extracellular loop of the NR1 subunit (Gazzaley et al., 1996). Oocytes were screened for NMDA currents in the range of 100-300 $\mathrm{nA}$ and ACPD potentiation of approximately twofold to threefold. Oocytes were incubated in $20 \mathrm{ml}$ of external recording solution in the absence or presence of ACPD (100 $\mu \mathrm{M}, 2 \mathrm{~min})$, devitellinized, and fixed in $4 \%$ paraformaldehyde and $2 \%$ sucrose $(1 \mathrm{hr}$ at room temperature). Oocytes were then incubated with NR1 antibody $\left(10 \mu \mathrm{g} / \mathrm{ml}, 4^{\circ} \mathrm{C}\right.$ overnight $)$, followed by biotinylated horse anti-mouse IgG (Vector Laboratories, Burlingame, CA; $10 \mu \mathrm{g} / \mathrm{ml}, 1.5 \mathrm{hr}$ at room temperature) and FITC-conjugated avidin (Vector Laboratories; $10 \mu \mathrm{g} / \mathrm{ml}$, $1.5 \mathrm{hr}$ at room temperature). Oocytes were rinsed, placed in a chamber $1.5 \mathrm{~mm}$ deep with a coverslip forming the bottom (MatTek, Ashford, MA), and covered with ProLong mounting medium (Molecular Probes, Eugene, OR) to reduce fluorescence quenching. Cross-sectional and tangential images of oocytes were viewed by a Bio-Rad MRC $600 \mathrm{Kr} / \mathrm{Ar}$ laser scanning confocal microscope and acquired using COMOS software (Bio-Rad, Hercules, CA). FITC fluorescence was measured (excitation wavelength, $488 \mathrm{~nm}$; emission, $515 \mathrm{~nm}$ ) with a $40 \times$ objective lens (aperture, 1.3); laser intensity, photomultiplier gain, and pinhole aperture were kept constant.

\section{RESULTS}

\section{Activation of mGluR1 $\alpha$ potentiates NMDA responses}

To examine the interaction between group I mGluRs and NMDARs, we coexpressed mGluR1 $\alpha$ with NR1-4b/NR2A receptors in Xenopus oocytes and examined the effect of mGluR activation on NMDA responses by whole-cell recording under voltage clamp. NR1-4b/NR2A and -B have the highest cell surface expression (Okabe et al., 1999) and highest degree of PKC potentiation (Zheng et al., 1999). Application of the mGluR agonist ACPD $(100 \mu \mathrm{M})$ in $\mathrm{Ca}^{2+}$-free Ringer's solution to the oocyte elicited a large inward current $(\sim 750 \mathrm{nA})$ that decayed to near baseline in $<30 \mathrm{sec}$ (Fig. $1 A$ ). The ACPD-elicited current is ascribable to $\mathrm{Cl}^{-}$efflux through $\mathrm{Ca}^{2+}$-activated $\mathrm{Cl}^{-}$channels endogenous to the oocyte (Saugstad et al., 1996). It is well documented that activation of mGluR1 can lead to an increase of $\left[\mathrm{Ca}^{2+}\right]_{\mathrm{i}}$ by activation of phospholipase $\mathrm{C}$ and release of $\mathrm{Ca}^{2+}$ from inositol triphosphate $\left(\mathrm{IP}_{3}\right)$-sensitive intracellular stores (Pin and Duvoisin, 1995). Hence, the ACPD-evoked current indicates effective expression of $\mathrm{mGluR} 1 \alpha$ and targeting of functional receptors to the cell surface of the oocyte.

To examine the effect of mGluR $1 \alpha$ activation on NMDAR responses, we recorded whole-cell currents elicited by NMDA (300 $\mu \mathrm{M}$ with $10 \mu \mathrm{M}$ glycine) before and after bath application of ACPD (100 $\mu \mathrm{M}, 2 \mathrm{~min})$ to the oocyte. Treatment with ACPD significantly increased NMDA-elicited responses (Fig. $1 A$; com- 

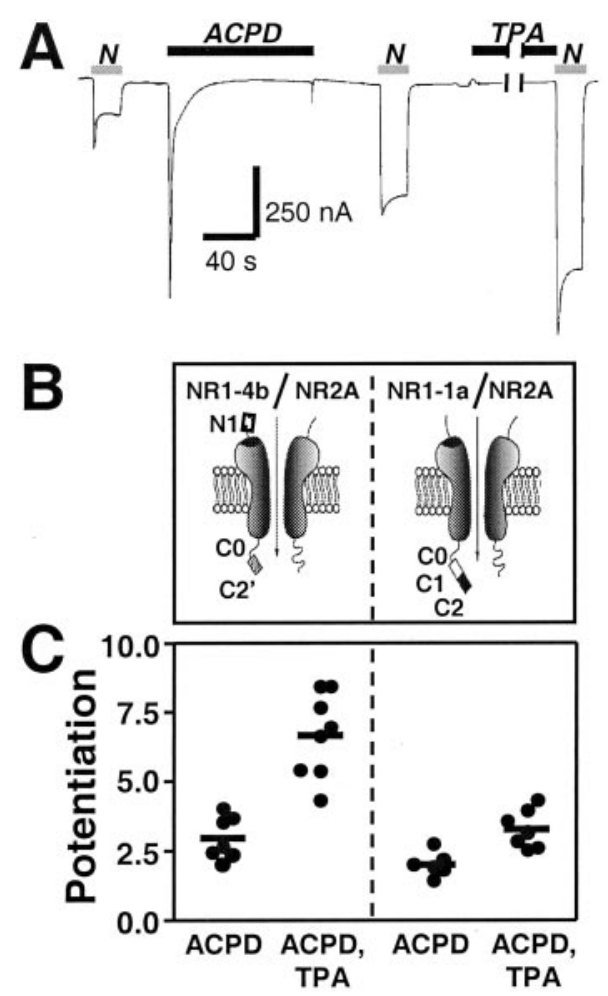

Figure 1. Activation of mGluR $1 \alpha$ potentiates NMDA whole-cell currents; alternative splicing of the NR1 subunit has little effect on ACPD potentiation. $A$, Typical sequence showing NMDA-activated whole-cell currents recorded in $\mathrm{Ca}^{2+}$ Ringer's solution at $V_{\mathrm{h}}=-60 \mathrm{mV}$ from oocytes expressing mGluR1 $\alpha$ and NR1-4b/NR2A receptors before and after application of ACPD (100 $\mu \mathrm{M}, 2 \mathrm{~min})$, followed by application of TPA (100 nM, $10 \mathrm{~min}$ ). NMDA, $300 \mu \mathrm{M}$; glycine, $10 \mu \mathrm{M}$. ACPD elicited a large inward current that decayed rapidly to near baseline within $30 \mathrm{sec}$, ascribable to $\mathrm{Cl}^{-}$efflux through $\mathrm{Ca}^{2+}$-activated $\mathrm{Cl}^{-}$channels endogenous to the oocyte. ACPD significantly potentiated NMDA responses. Application of the phorbol ester TPA to oocytes after ACPD treatment further potentiated NMDA responses. $B$, Schematic representation of the NR1 splice variants. $N 1, C 1, C 2$, and $C 2^{\prime}$ are alternatively spliced cassettes; $\mathrm{CO}$ is the region between the fourth transmembrane domain and the first splice site in the C terminal (Zheng et al., 1999). C, Summary of several experiments illustrating that ACPD potentiation did not differ significantly for NR1-4b/NR2A versus NR1-1a/NR2A receptors. In contrast, potentiation by TPA (applied to oocytes after ACPD) was significantly greater for NR1-4b/NR2A receptors compared with NR1-1a/ NR2A receptors ( $p<0.01$, one-way ANOVA followed by Bonferroni's $t$ test). Each data point is from a single experiment; horizontal bars represent the means.

pare first and second NMDA responses). In $\mathrm{Ca}^{2+}$ Ringer's solution, ACPD potentiation (defined as the ratio of NMDA current amplitude measured after ACPD to that measured before ACPD) was $2.97 \pm 0.30(n=7)$ (Fig. $1 C)$.

To investigate the effect of alternative splicing of the NR1 subunit on mGluR1-mediated potentiation of NMDAR responses, we coexpressed mGluR1 $\alpha$ with either NR1-1a/NR2A $\left(\mathrm{NR} 1_{011} / \mathrm{NR} 2 \mathrm{~A}\right)$ or $\mathrm{NR} 1-4 \mathrm{~b} / \mathrm{NR} 2 \mathrm{~A}\left(\mathrm{NR} 1_{100} / \mathrm{NR} 2 \mathrm{~A}\right)$ receptors in Xenopus oocytes (Fig. 1B). NR1-1a/NR2A and -B have the lowest cell surface expression (Okabe et al., 1999) and lowest degree of PKC potentiation (Zheng et al., 1999). Application of ACPD potentiated NMDA responses of NR1-4b/NR2A receptors to $2.97 \pm 0.30$ times the control response in $\mathrm{Ca}^{2+}$ Ringer's solution $(n=7)$ (Fig. 1A,C). ACPD potentiated responses of $\mathrm{NR} 1-1 \mathrm{a} / \mathrm{NR} 2 \mathrm{~A}$ receptors to $2.03 \pm 0.18$ times the control response in $\mathrm{Ca}^{2+}$ Ringer's solution $(n=7)$ (Fig. $1 C$ ). Differences in
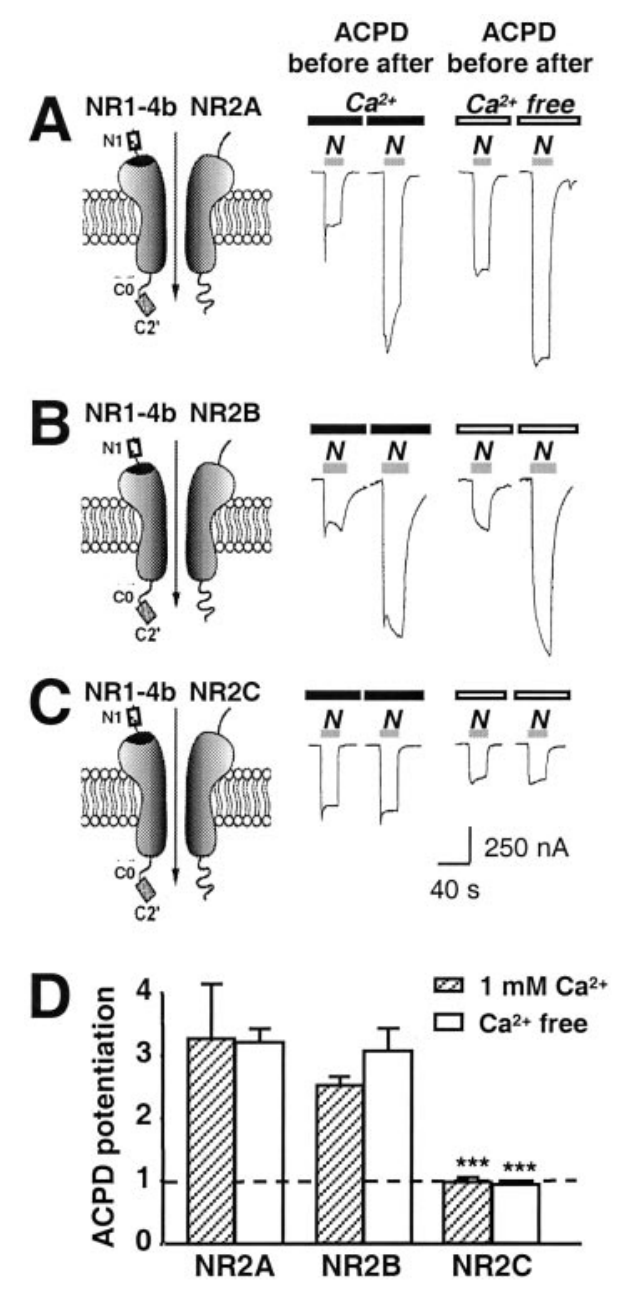

Figure 2. The NR2 subunit alters ACPD potentiation. NMDA-activated whole-cell currents were recorded in $\mathrm{Ca}^{2+}$ or $\mathrm{Ca}^{2+}$-free Ringer's solution from oocytes expressing mGluR $1 \alpha$ and NMDARs. $A-C$, ACPD $(100 \mu \mathrm{M}$, $2 \mathrm{~min}$ ) potentiated NMDA currents in oocytes expressing NR1-4b/ NR2A or NR1-4b/NR2B receptors; no potentiation was observed for $\mathrm{NR} 1-4 \mathrm{~b} / \mathrm{NR} 2 \mathrm{C}$ receptors. $\mathrm{N1}, \mathrm{CO}$, and $C 2^{\prime}$ are defined in the legend to Figure 1. $D$, Summary of three experiments illustrating $\sim 3.33$-fold potentiation by ACPD of NR1-4b/NR2A and 2.57-fold for NR1-4b/NR2B receptors in $\mathrm{Ca}^{2+}$ Ringer's solution but little or no potentiation of NR1-4b/NR2C receptors.

ACPD-induced potentiation between splice variants did not reach statistical significance in either $\mathrm{Ca}^{2+}$ - containing or $\mathrm{Ca}^{2+}$ free $\left(\mathrm{Ba}^{2+}\right)$ Ringer's solution (one-way ANOVA followed by Bonferroni test, $p>0.05$ for comparisons between each receptor pair). The smaller magnitude of the mGluR $1 \alpha$ potentiation may have obscured an effect of NR1 splicing similar to that observed for PKC potentiation (Zheng et al., 1999).

To investigate the effects of the NR2 subunit on ACPDinduced potentiation, we coexpressed mGluR $1 \alpha$ with NR1-4b/ NR2A, NR1-4b/NR2B, or NR1-4b/NR2C receptors in Xenopus oocytes. The mGluR1 agonist ACPD $(100 \mu \mathrm{M})$ significantly potentiated NMDA-induced currents of NR1-4b/NR2A and NR1-4b/NR2B receptors $(n=3)$ (Fig. $2 A, B)$. Potentiation was to $3.33 \pm 0.88(n=3)$ (Fig. $1 A)$ and $2.57 \pm 0.14(n=3)$ times the control responses in $\mathrm{Ca}^{2+}$ Ringer's solution, respectively (Fig. $2 D)$. The degree of ACPD potentiation did not differ significantly for NR1-4b/NR2A versus NR1-4b/NR2B receptors. As observed for TPA potentiation (Mori et al., 1993), ACPD did not 
potentiate responses of NR1-4b/NR2C receptors $(n=3)$ (Fig. $2 C)$; potentiation was to $1.02 \pm 0.04$ times the control response in $\mathrm{Ca}^{2+}$ Ringer's solution $(n=3)$ (Fig. $\left.2 D\right)$. Similar results were observed for the three receptor subtypes in $\mathrm{Ba}^{2+}$ Ringer's solution. Thus, the NR2 subunit composition of NMDAR affected the degree of ACPD potentiation.

To rule out the possibility that ACPD directly activates NMDA receptors (the mGluR agonist 2- $\left(2^{\prime}, 3^{\prime}\right)$-dicarboxycyclopropylglycine at high concentrations may act on the NMDA receptor as an agonist) (Opitz et al., 1994; Yu et al., 1997), we applied a high concentration of ACPD $(100 \mu \mathrm{M})$ to oocytes expressing NR1-4b/ $\mathrm{NR} 2 \mathrm{~A}$ receptors in the absence of $\mathrm{mGluR} 1 \alpha$. Under these conditions, ACPD elicited no response and did not potentiate NMDA currents (data not illustrated), indicating that the $\mathrm{Cl}^{-}$ response was mGluR-dependent and that ACPD did not activate or potentiate NMDA channels directly.

\section{ACPD increases $n p_{0}$ but not conductance or open time}

To examine effects of mGluR1 activation on NMDA channel conductance and gating, we recorded channel activity in outsideout patches excised from oocytes expressing mGluR1 $\alpha$ and NR1$4 b / N R 2 A$ receptors before and after ACPD treatment. We compared patches excised before and after ACPD treatment, because patch formation inhibits exocytosis, presumably by deformation of the membrane and disruption of association with cytoplasmic elements (Lan et al., 2001)

In control patches, NMDA $(10 \mu \mathrm{M})$ activated single channels with a conductance of $\gamma=44 \pm 1 \mathrm{pS}$ at $-60 \mathrm{mV}$, which did not vary with voltage $(n=5)$ (Fig. $3 A, D)$. Occasional transitions from the main conductance state to sublevels (total dwell time of $<1 \%$ of that of the main state; data not shown) were excluded from the analysis. NMDA channel activity in patches excised after application of ACPD (100 $\mu \mathrm{M}, 2 \mathrm{~min})$ was markedly potentiated (Fig. $3 A, B)$. ACPD increased $n p_{\mathrm{o}}$ by approximately fourfold from $0.050 \pm 0.006$ before $\mathrm{ACPD}(n=5)$ to $0.209 \pm 0.027$ after ACPD $(n=5 ; p<0.001)$ (Fig. $3 C)$.

mGluR1 activation did not alter NMDA single-channel conductance $(n=5)$ (Fig. $3 A, B)$ or reversal potential $\left(E_{\mathrm{rev}} \sim 0\right)$, as evidenced by comparison of current-voltage relationships $(n=5)$ (Fig. $3 D$ ). Moreover, ACPD did not significantly change the mean duration of openings (Fig. $3 E, F)$. The distribution of open times was fit by a single exponential, consistent with the presence of a single open state (Fig. $3 E, F)(\tau=6.35 \pm 0.26 \mathrm{msec}$ before ACPD; $n=5$; vs $\tau=6.08 \pm 0.29 \mathrm{msec}$ after ACPD; $n=5)$. Potentiation of $n p_{\mathrm{o}}$ without change in $\gamma$ was also induced by the mGluR agonist $(S)$-3,5-dihydroxyphenylglycine (100 $\mu \mathrm{M}$; data not shown).

\section{mGluR1 activation induces an increase in the number of active NMDA channels}

The results reported thus far indicate that ACPD increases the number of active channels in the cell membrane times the open probability. To distinguish between effects of mGluR1 activation on the number of functional channels in the membrane, $n$, and channel open probability, $p_{\mathrm{o}}$, we recorded NMDA whole-cell currents in the presence of MK-801 (5 $\mu \mathrm{M})$ from control (Fig. $4 B$, left trace) and ACPD-treated (Fig. 4B, right trace) oocytes by a modification of the method of Jahr (1992) as adapted by Rosenmund et al. (1995). This method takes advantage of the essentially irreversible block of NMDA-elicited currents by the openchannel blocker MK-801. To determine the number of channels in the whole oocyte, $N$, we calculated the cumulative charge transfer, $Q$, which is the integral of NMDA-elicited current dur-
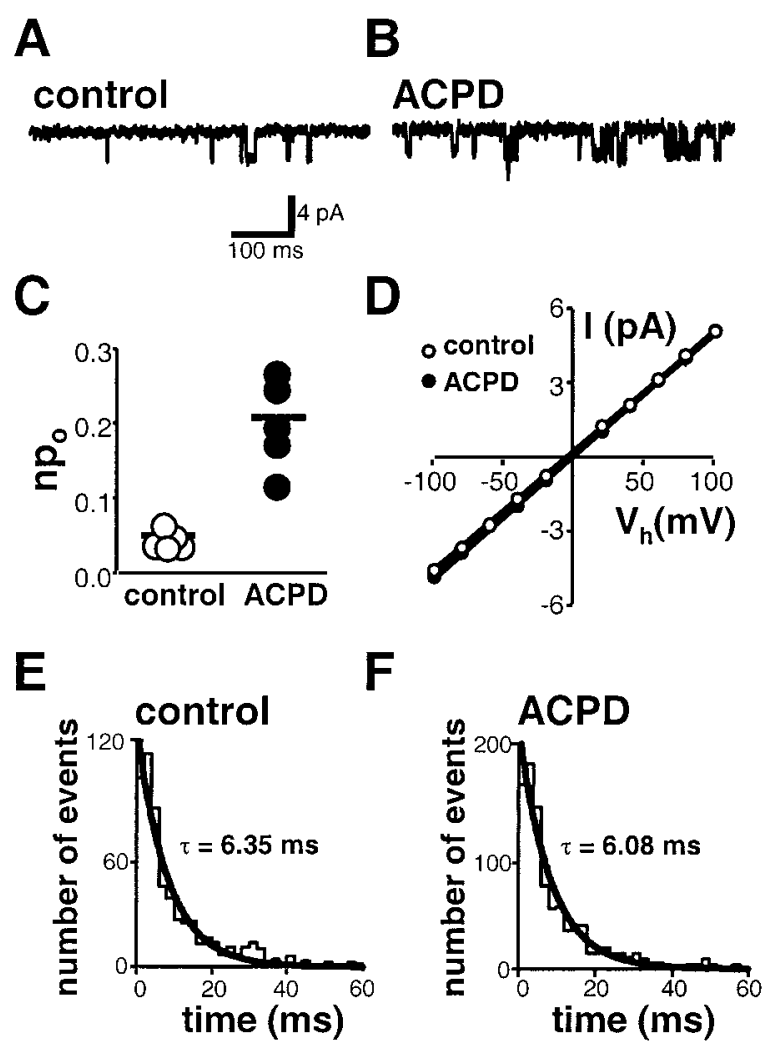

Figure 3. ACPD potentiates $n p_{\mathrm{o}} . A, B, \mathrm{NMDA}$-activated single channels recorded from outside-out patches excised from oocytes expressing recombinant $\mathrm{NR} 1-4 \mathrm{~b} / \mathrm{NR} 2 \mathrm{~A}$ and $\mathrm{mGluR} 1 \alpha$ receptors; patches were excised before $(A)$ and after $(B)$ application of ACPD $(100 \mu \mathrm{M}, 2 \mathrm{~min})$. NMDA, $100 \mu \mathrm{M}$; glycine, $10 \mu \mathrm{M}$. The main unitary conductance was $44 \pm$ $1 \mathrm{pS}$ at $V_{\mathrm{h}}=-60 \mathrm{mV}$. $C$, ACPD treatment potentiated the $n p_{\mathrm{o}}$ from $0.050 \pm 0.006$ recorded from patches excised before ACPD $(n=5)$ to $0.204 \pm 0.034$ recorded from different patches excised from the same oocytes after ACPD treatment $(n=5 ; p<0.001)$. $D$, Single-channel current-voltage relationships. ACPD did not alter the main unitary conductance of NMDA-activated channels $(44 \pm 1 \mathrm{pS}$ before ACPD; $n=5$; vs $44 \pm 1 \mathrm{pS}$ after ACPD; $n=5)$. ACPD treatment did not affect the reversal potential $\left(E_{\mathrm{rev}}=0 \mathrm{mV}\right.$ before ACPD; $n=5$; and $0 \mathrm{mV}$ after ACPD; $n=5)$. $E, F$, Histograms of mean open time durations for NMDA-activated channels before and after application of ACPD to the oocyte. Mean open times were determined by a single exponential fit to the event lists generated by single opening and closing events. ACPD did not alter the mean open time.

ing the time required for complete block by MK-801. The number of channels, $N$, can be calculated from $Q$ as follows:

$$
N=Q /\left[\gamma\left(\mathrm{V}-E_{\mathrm{rev}}\right) t_{\mathrm{bl}}\right],
$$

where $t_{\mathrm{bl}}$ is the time constant for MK-801 block $\left(t_{\mathrm{bl}}=1 / k_{\mathrm{bl}}\right.$ [MK-801], and $\left.k_{\mathrm{bl}}=2.5 \times 10^{7} \mathrm{M} / \mathrm{sec} ; \mathrm{Jahr}, 1992\right)$. From the single-channel recordings (Fig. 3), ACPD does not change singlechannel conductance, and we would not expected it to change $t_{\mathrm{bl}}$. The channel number, $N$, for control and ACPD-treated oocytes was normalized to the NMDA-elicited whole-cell current, which corrects for any differences in levels of expression within and between the two groups. For control oocytes, which exhibited control currents in the range of $100-300 \mathrm{nA}$, the mean number of channels per $100 \mathrm{nA}$ was $6.8 \pm 0.8 \times 10^{5}$, and the mean channel density for $100 \mathrm{nA}$ was $0.02 \mu \mathrm{m}^{-2}$, assuming a surface area for the oocyte of $3 \times 10^{7} \mathrm{\mu m}^{2}$ (Zampighi et al., 1999). ACPD increased $N \sim 1$.6-fold $\left(N_{\mathrm{ACPD}} / N_{\text {control }}=1.6 ; p<0.01\right)$. This 

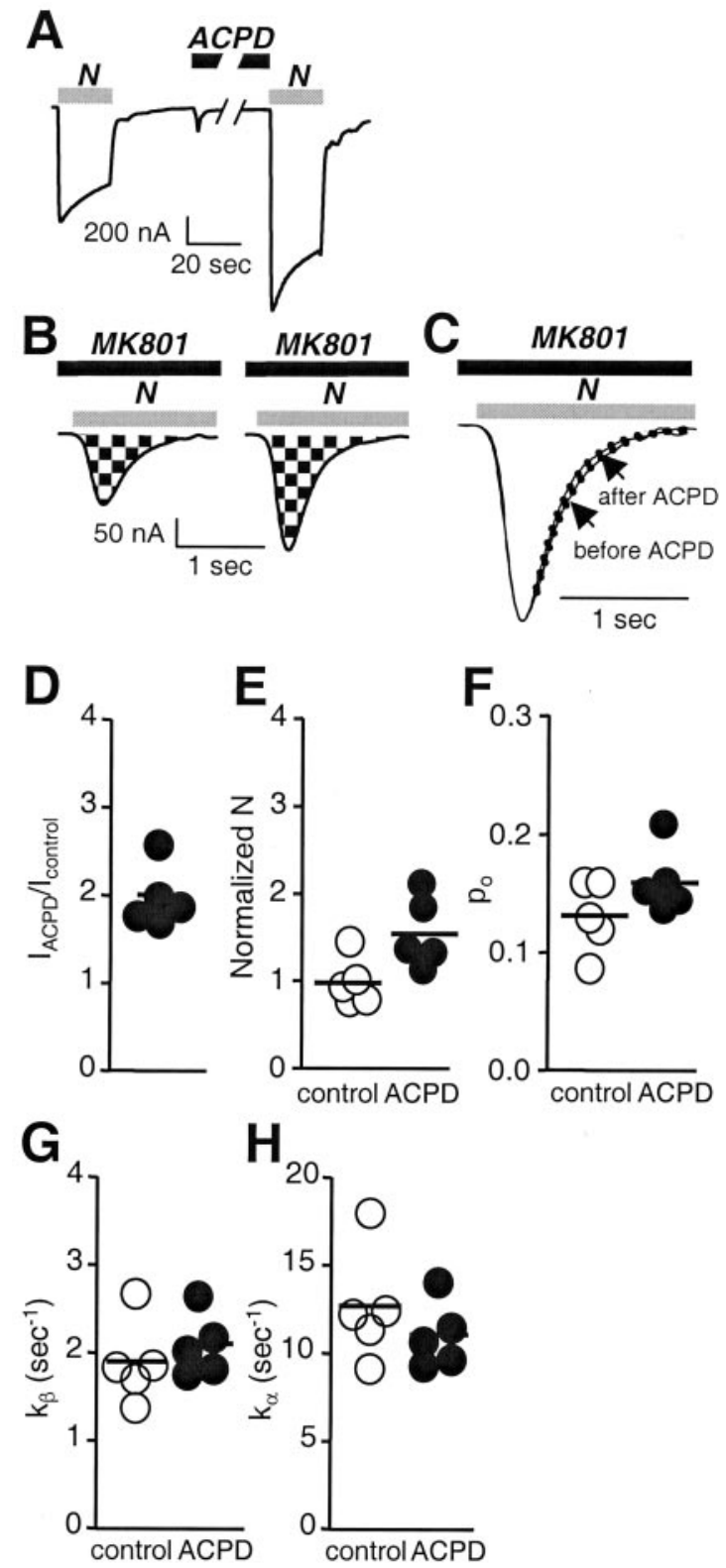

Figure 4. mGluR $1 \alpha$ activation increases NMDA channel number and modestly (but not significantly) increases open probability. A, ACPD (100 $\mu \mathrm{M}, 2 \mathrm{~min}$ ), bath-applied, potentiated whole-cell currents elicited by application of NMDA (1 mM with $50 \mu \mathrm{M}$ glycine). To avoid contributions by $\mathrm{Ca}^{2+}$ inactivation, $\mathrm{Ca}^{2+}$ amplification to NMDA responses, or both, recording was in $\mathrm{Ba}^{2+}$ Ringer's solution as the extracellular solution. $V_{\mathrm{h}}=$ $-60 \mathrm{mV}$. B, ACPD increased the number of functional NMDA channels expressed at the cell surface $(N)$. Currents were elicited by application of NMDA (1 mM NMDA with $50 \mu \mathrm{M}$ glycine) in the continuous presence of the open channel blocker MK-801 $(5 \mu \mathrm{M})$ from control (left) and ACPDtreated (right) oocytes at a holding potential of $-60 \mathrm{mV}$. The NMDA inward current increased to a peak value, after which it decayed exponentially as MK-801 entered and blocked NMDA channels as they opened. The cumulative charge transfer, $Q$, which is the total current flow during the time interval for complete block by MK-801, was obtained by integration of the current trace over time. The larger integrated current in ACPD-treated oocytes indicated an increased number of functional channels per cell. $C$, Agonist-evoked currents in $B$ were normalized to the same peak amplitude and used for kinetic analysis. The more rapid decay of the NMDA current in ACPD-treated oocytes versus control in this pair of oocytes indicates an increased rate of channel opening, $k_{\beta}$, but the difference was not significant in the pooled data. $D-H$, Quantization of data in $A-C$. $D$, Potentiation of NMDA whole-cell current, $I_{\mathrm{ACPD}} / I_{\text {control }}$, was $2.2 \pm 0.2$ times control $(p<0.001 ; n=5)$. $E$, The increase in analysis indicates that mGluR1 activation increases the number of functional NMDA channels per cell.

The data in Figure $4 B$ also enabled us to analyze the effect of mGluR1 activation on NMDA channel gating. We first calculated channel open probability in control and ACPD-treated oocytes from the NMDA-elicited whole cell current, $I$, the single-channel current, $i$ (which is not changed by mGluR1 activation) (Fig. 3D), and the number of channels per cell, $N$, as follows:

$$
\begin{aligned}
& p_{\text {o,control }}=I_{\text {control }} / i N_{\text {control }}=0.13 \pm 0.01 \\
& p_{\mathrm{o}, \mathrm{ACPD}}=I_{\mathrm{ACPD}} / i N_{\mathrm{ACPD}}=0.16 \pm 0.01,
\end{aligned}
$$

from which $p_{\mathrm{O}, \mathrm{ACPD}} / p_{\mathrm{o}}$, control $=1.2$. The ACPD-induced increase in channel open probability was not significant.

As an independent measure of the effect of mGluR1 activation on channel gating, we analyzed the decay of NMDA-elicited current in the presence of MK-801 from the data in Figure $4 B$ normalized to the same peak amplitude (Fig. $4 C$ ). Provided that $k_{\mathrm{b} 1}[\mathrm{MK}-801] \gg k_{\alpha}$ and $k_{\beta}$ (the closing and opening rates, respectively), the decay can be described by a single exponential with a rate constant, $k_{\beta}$, for channel opening. Activation of mGluR1 did not significantly change $k_{\beta}(1.9 \pm 0.2 / \mathrm{sec}$ for control oocytes vs $2.1 \pm 0.2 / \mathrm{sec}$ for ACPD-treated oocytes) (Fig. 4G). From measurements of $p_{\mathrm{o}}$ and $k_{\beta}$ and the relation $p_{\mathrm{o}}=k_{\beta} /\left(k_{\alpha}+\right.$ $k_{\beta}$ ), we calculated values of $k_{\alpha}=12.7 \pm 1.5 / \mathrm{sec}$ in control oocytes versus $11.1 \pm 0.8 / \mathrm{sec}$ in ACPD-treated oocytes (Fig. $4 H$ ). These values of $k_{\alpha}$ are substantially less than the value of $\sim 167 / \mathrm{sec}$ predicted from the $\sim 6 \mathrm{msec}$ mean open time of single channels. The apparent discrepancy arises because the $p_{\mathrm{o}}$ equation as applied to macroscopic current assumes an equilibrium between unliganded and bursting states and thus will yield a $k_{\alpha}$ value corresponding to termination of bursting rather than of individual openings. Moreover, $k_{\alpha}$ calculated in this manner will be overestimated in that the probability that a receptor is liganded is greater than the probability that it is open, $p_{\mathrm{o}}$, calculated from $N$ and $I$.

\section{mGluR1 activation delivers NMDA channels to the cell membrane via exocytosis}

The results reported thus far indicate that mGluR1 activation induces an increase in the number of active channels at the cell surface but does not distinguish between insertion of new NMDA channels and unmasking of silent channels. To distinguish between these possibilities, we performed two additional experiments. First, we examined the effects of loading oocytes with the light chains of type A botulinum neurotoxin (BoNT A), which is known to inactivate SNAP-25 and to prevent SNAP-25dependent exocytosis (Montecucco and Schiavo, 1995). Treatment of oocytes with BoNT A reduced the degree of mGluR1mediated potentiation of NMDA-elicited currents by $\sim 50 \%$ (Fig. $5 A-C)$. A mixture of type $\mathrm{A}, \mathrm{B}$, and $\mathrm{E}$ BoNTs reduced ACPD potentiation by $\sim 60 \%$ (Fig. $5 C$ ). No significant change in the resting potential, input resistance, and basal NMDA response was caused by BoNTs (data not shown). BoNT A also reduces TPA potentiation by $\sim 50 \%$ (Lan et al., 2001). No effects on

channel number, $N$, was significant $(p<0.01)$, and $N_{\mathrm{ACPD}} / N_{\text {control }}=1.6$ $(n=5) . F$, The open probabilities were not significantly different $\left(p_{\mathrm{o}}\right.$, control $=0.13 \pm 0.01 ; p_{\mathrm{o}, \mathrm{ACPD}}=0.16 \pm 0.01 ; p_{\mathrm{o}, \text { control }} / p_{\mathrm{o}, \mathrm{ACPD}}=1.2 ; n=$ 5). $G$, Opening rates, $k_{\beta}$, for control $(1.9 \pm 0.2 / \mathrm{sec})$ and ACPD-treated oocytes $(2.1 \pm 0.2 / \mathrm{sec} ; p<0.01)$. $H$, Closing rates, $k_{\alpha}$, for control (12.7 \pm $1.5 / \mathrm{sec})$ and ACPD-treated oocytes $(11.1 \pm 0.8 / \mathrm{sec})$. 


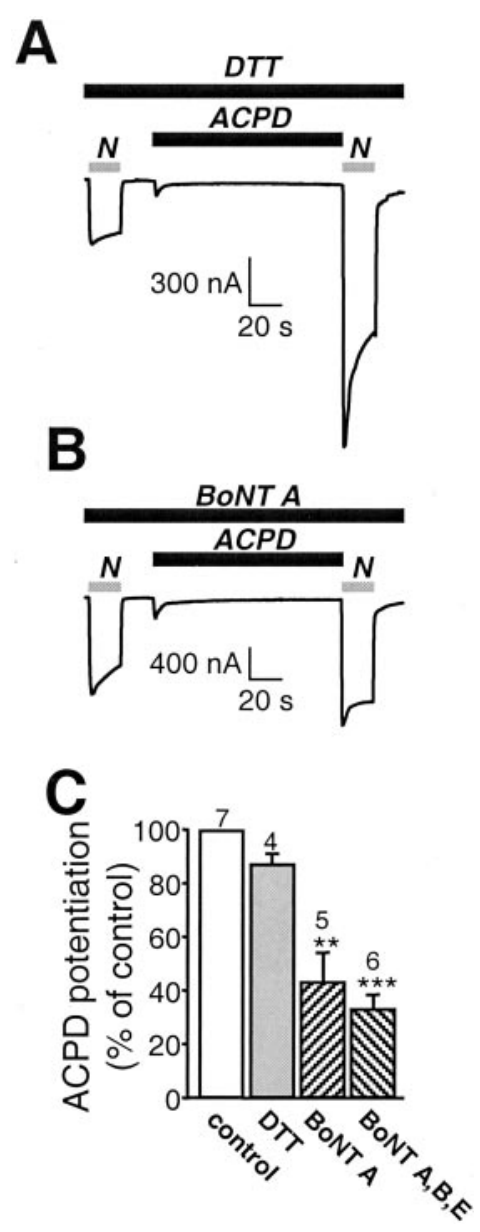

Figure 5. mGluR $1 \alpha$ promotes delivery of NMDA channels to the cell membrane via exocytosis. $A-C$, Microinjection of the light chain of botulinum toxin type A BoNT (50 ng), an enzyme known to cleave SNAP-25, into oocytes $5 \mathrm{hr}$ before recording reduced ACPD potentiation of NMDA-elicited currents by $\sim 50 \%$. $A, B$, Representative NMDAelicited whole-cell currents in an oocyte loaded with $50 \mathrm{nl}$ of DTT (5 mM) in $A$ and $50 \mathrm{ng}$ of BoNT A and DTT in $B$ before and after ACPD application. BoNT A reduced potentiation but not basal NMDA-elicited currents or ACPD-elicited $\mathrm{Cl}^{-}$currents. $C$, Quantification of $A$ and $B$. A mixture of type $\mathrm{A}, \mathrm{B}$, and $\mathrm{E}$ BoNTs reduced ACPD potentiation by $60 \%$.

mGluR1-mediated potentiation were observed when only the vehicle (10 mM DTT) was injected. Presumably, toxin treatment attenuated the number of new channels inserted by mGluR1 activation.

Second, we examined the ability of a dominant negative mutant of SNAP-25 to block mGluR1-mediated potentiation. SNAP$25(\Delta 20)$, a truncation mutant lacking the C-terminal 20 amino acids, corresponds to yeast sec9- $\Delta 17$, a dominant negative mutant of the yeast SNAP-25 homolog (Yao et al., 1999). Mutant and wild-type SNAP-25 were expressed in oocytes by injection of their cRNAs $48 \mathrm{hr}$ after injection of NMDAR cRNAs, and ACPD potentiation was measured $\sim 20 \mathrm{hr}$ later. ACPD-induced potentiation of NMDA currents in control oocytes $(2.5 \pm 0.3 ; n=$ 3) (Fig. 6A,D) and in oocytes expressing full-length SNAP-25 $(2.9 \pm 0.2 ; n=4)$ (Fig. 6B,D) was greater than in oocytes expressing SNAP-25 $(\Delta 20)(1.5 \pm 0.2 ; n=5 ; p<0.01)$ (Fig. $6 C, D)$. Expression of SNAP-25 $(\Delta 20)$ did not affect the NMDAelicited current or endogenous $\mathrm{Ca}^{2+}$-activated $\mathrm{Cl}^{-}$currents. These findings indicate that NMDA channels inserted at the cell surface by mGluR $1 \alpha$ activation are delivered, at least in part, by

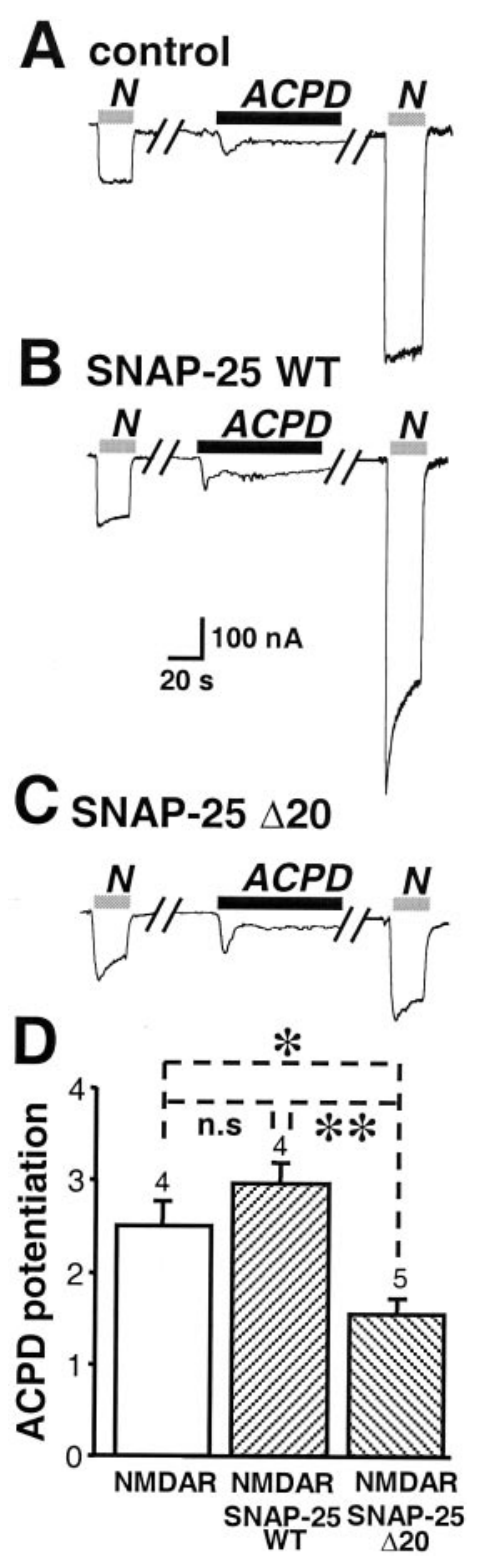

Figure 6. A dominant negative mutant of SNAP-25 reduces ACPD potentiation of NMDARs. $A$, ACPD potentiation of NMDA-elicited currents in oocytes expressing mGluR1 $\alpha$ and NR1-4b/NR2A receptors as in Figure $2 A$. $B$, Coexpression of wild-type SNAP-25 with NMDARs had no effect on ACPD potentiation. $C$, Coexpression of SNAP-25( $\Delta 20)$, a dominant negative mutant of SNAP-25, with NMDARs markedly reduced ACPD potentiation. $D$, Quantification of the effects of wild-type and mutant SNAP-25 on ACPD potentiation.

SNAP-25-mediated soluble $N$-ethylmaleimide sensitive fusion protein attachment protein receptor (SNARE)-dependent exocytosis.

Although the data indicate that ACPD increases the number of functional NMDA channels at the cell surface via a SNAREdependent mechanism, they do not exclude a contribution from reduction in internalization (or another mechanism of silencing). As an estimate of the rate of constitutive exocytosis in the oocyte, we measured reappearance of functional channels at the cell surface after quasi-irreversible block by MK-801. MK-801 (1 $\mu \mathrm{M})$ blocked completely the NMDA-elicited current (Fig. 7A, first response). A test application of NMDA at 3 min elicited a small response, indicative of a small number of newly inserted channels, 

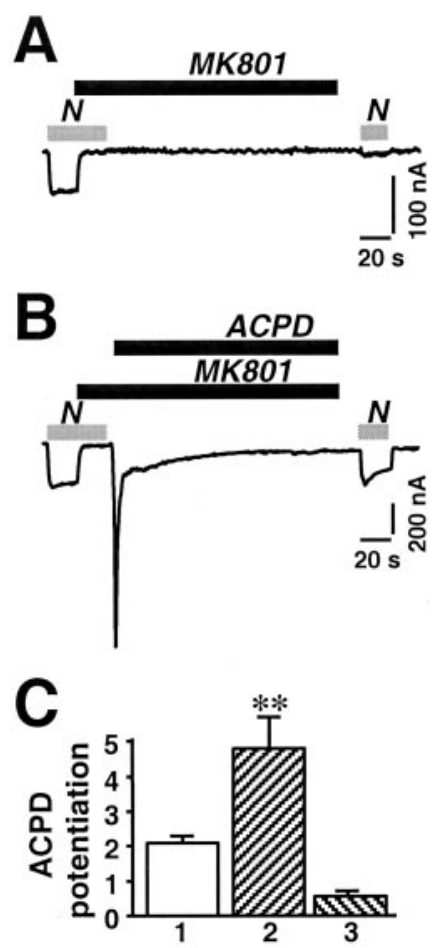

Figure 7. mGluR $1 \alpha$ potentiation increases the rate of exocytosis of NMDA channels in the cell membrane. Whole-cell recordings were obtained from Xenopus oocytes expressing NR1-4b/NR2A receptors in $\mathrm{Ca}^{2+}$-free Ringer's solution. The open channel blocker MK-801 $(1 \mu \mathrm{M})$ was used to estimate the rate of delivery of functional channels to the cell surface in control and ACPD-treated oocytes. NMDA, $300 \mu \mathrm{M}$; glycine, $10 \mu \mathrm{M}$. A, Application of MK-801 $(1 \mu \mathrm{M})$ in the presence of agonist completely blocked the NMDA response. Three minutes after block and washout of NMDA, MK-801 was removed; then a test application of NMDA elicited a very small response ( $\sim 10 \%$ of control), attributable to either recovery of a small number of channels from block or insertion of new channels. $B$, After complete block of the NMDA response by MK$801(1 \mu \mathrm{M})$, ACPD $(100 \mu \mathrm{M})$ was applied for $2 \mathrm{~min}$ in the continuous presence of MK-801. After washout of ACPD and MK-801, the peak of the NMDA-induced response was slightly smaller than that of the control response. The greater decay of this response is ascribable to residual MK-801. $C$, Quantitation of data in $A$ and $B$. Test responses were normalized to initial currents. Bar $1, I_{\mathrm{ACPD}} / I_{\text {control }}$, where $I_{\mathrm{ACPD}}$ is the NMDA-elicited current after ACPD. In this batch of oocytes. ACPDinduced potentiation was to $\sim 2$ times the control response. Bar 2, $I_{\mathrm{ACPD}, \mathrm{MK}-801} / I_{\mathrm{MK}-801}$, where $I_{\mathrm{ACPD}, \mathrm{MK}-801}$ is the current after block of the control response by MK- 801 and potentiation by ACPD, and $I_{\mathrm{MK}-801}$ is the current after block of the control response by MK- 801 followed by 3 min recovery. In the presence of MK-801, ACPD potentiation was to 4.5 times the recovered response observed after block by MK-801 in $A$, a value that could not be accounted for by twofold potentiation of the recovered response. Bar 3, $I_{\mathrm{ACPD}}, \mathrm{MK}-801 / I_{\text {control }}$. The potentiation measured as the ratio of the potentiated response after MK- 801 block to the control response was somewhat smaller than the potentiated response without MK-801 minus the control response.

which were opened by the agonist (Fig. $7 A$, second response). The small size of the test response is indicative of a relatively slow rate of constitutive exocytosis and is consistent with the half-time of $\sim 40$ min reported for recovery of the acetylcholine response after irreversible block of nicotinic acetylcholine receptors expressed in Xenopus oocytes (Akabas et al., 1992). Because under steady-state conditions, the rate of internalization equals the rate of exocytosis, the rate of internalization is slow (Fig. $7 A$ ), and a reduction in the rate of internalization (or of silencing) could account for, at most, a very small fraction of the potentiation by ACPD.
As a further test of ACPD-induced recruitment of new channels to the cell surface, we blocked NMDA currents with MK-801 as in Figure $7 A$ and then applied ACPD in the presence of MK-801 (Fig. 7B). In these oocytes, a test application of NMDA elicited a much larger response, $\sim 4.5$ times that observed in control oocytes at 3 min after MK-801 block (Fig. 7A) $(p<0.01)$ and approximately the same size as the control response $(p<$ 0.001) (Fig. 7C). If ACPD potentiation were attributable entirely to insertion of new channel molecules (Fig. 4), and constitutive insertion were negligible, the amplitude of the test NMDA current after ACPD application in the presence of MK-801 $\left(I_{\mathrm{ACPD}}\right.$, MK-801) would equal the amplitude of the test NMDA current after ACPD alone $\left(I_{\mathrm{ACPD}}\right)$ minus the amplitude of the initial control current $\left(I_{\text {control }}\right)$. $I_{\mathrm{ACPD}}$, MK-801 was slightly smaller than the predicted value, possibly an effect of residual MK-801 (Fig. $5 D$, bars 1, 3). These findings demonstrate that ACPD causes a rapid increase in the number of functional NMDARs in the cell surface.

\section{ACPD increases surface expression of NMDARs}

The electrophysiological experiments presented thus far argue for mGluR1-mediated increase in the number of active channels via exocytosis but do not provide a measure of the total number of channel molecules expressed at the surface. To examine the effect of mGluR $1 \alpha$ on the surface expression of NMDARs, we performed cell surface Western blots by a modification of the method of Chen et al. (1999). Control and ACPD-treated oocytes expressing mGluR1 $\alpha$ and NR1/NR2A receptors were surfacelabeled with sulfo-NHS-SS-biotin, and surface proteins were separated from intracellular proteins by reaction with Neutravidin beads and centrifugation. Samples of surface and total cell protein were treated with DTT (which releases the biotin moiety from surface proteins) and subjected to electrophoresis. Membranes were probed with antibody 54.1, a monoclonal antibody directed to the extracellular loop of the NR1 subunit (Gazzaley et al., 1996) (Fig. 8A). Analysis of band densities indicated an increase in surface NR1 expression to $1.7 \pm 0.2$ times control $(n=4 ; p<0.01)$ (Fig. 8B,D), with no change in total cell NR1 protein (Fig. $8 C$ ).

In addition, we assessed the effect of $\mathrm{mGluR} 1 \alpha$ activation on receptor surface expression by immunofluorescence. Control and ACPD-treated nonpermeabilized oocytes expressing NR1-4b/ $\mathrm{NR} 2 \mathrm{~A}$ and $\mathrm{mGluR} 1 \alpha$ receptors were reacted with antibody 54.1, followed by a biotinylated secondary antibody and fluoresceinconjugated avidin. Optical sections through the oocyte were viewed by confocal microscopy and captured by COMOS software. Control oocytes expressing NMDARs exhibited clear immunofluorescence, which appeared concentrated at the external surface (Fig. 9A,C). ACPD dramatically increased NR1 surface immunolabeling (Fig. 9B,D). Little or no immunofluorescence was observed for oocytes reacted with the FITC-tagged secondary antibody in the absence of the primary antibody (Fig. 9E) or for water-injected oocytes labeled with the N-terminal antibody (Fig. 9F). These findings indicate specificity of the immunofluorescence labeling. ACPD did not increase the resting conductance of the oocytes after the $\mathrm{Ca}^{2+}$-activated $\mathrm{Cl}^{-}$current subsided. Moreover, control experiments indicate that TPA treatment does not increase the permeability of the oocyte membrane to the antibody (Lan et al., 2001). We therefore infer that ACPD is unlikely to affect the permeability of the oocyte membrane. 


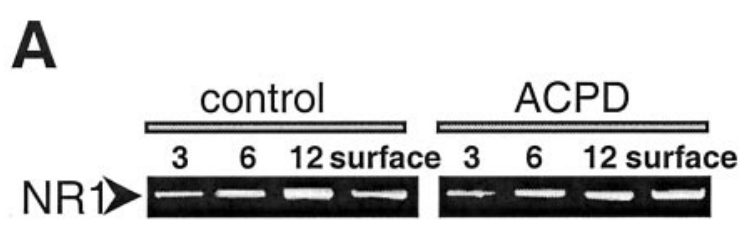

B

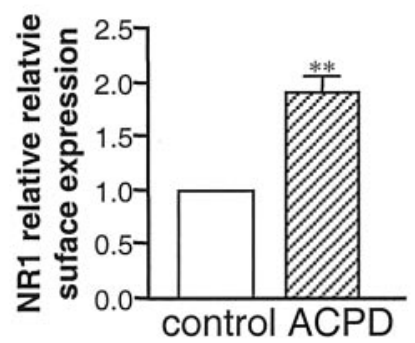

C

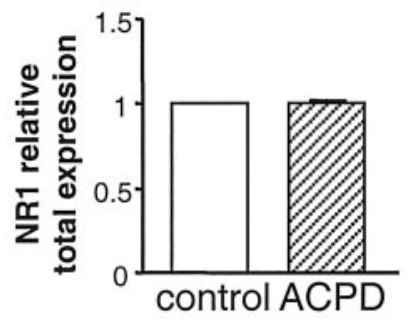

D

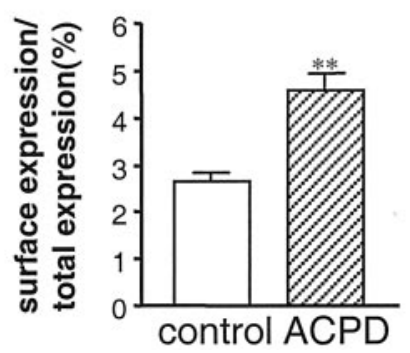

Figure 8. mGluR $1 \alpha$ increases NMDAR surface expression. NR1 surface and total cell expression in control and ACPD-treated oocytes is shown, as assessed by Western blot analysis of surface proteins isolated by biotinylation. $A$, Representative Western blot of surface protein from oocytes expressing NR1-4b/NR2A with mGluR $1 \alpha$ receptors probed with anti-NR1 antibody 54.1.3, 6, 12, Micrograms of protein in samples of total cell extract before Neutravidin bead extraction loaded on each lane; surface, aliquot of Neutravidin bead-isolated receptors. $B-D$, Quantitative analysis of the effects of ACPD on surface expression $(B)$, total cell protein $(C)$, and fractional surface expression $(D)$ of NMDARs. Surface expression was increased to $1.7 \pm 0.2$ times control $(n=4 ; p<0.01)$. Total cell NR1 was not changed. The proportion of NR1 expressed at the cell surface increased from 2.6 to $4.5 \%$.

\section{DISCUSSION}

Modulation of ligand-gated channels by G-protein-linked receptors is likely to be an important mode of receptor regulation under physiological conditions. The present study demonstrates that mGluR $1 \alpha$-mediated potentiation of NMDARs in Xenopus oocytes is mediated by recruitment of new channel molecules to the cell surface via regulated exocytosis. We show that loading cells with BoNT A, which interferes with exocytosis by cleaving SNAP-25, markedly reduces ACPD potentiation of NMDAR responses. Moreover, expression of a dominant negative mutant of SNAP-25, SNAP-25( $\Delta 20)$, nearly abolishes ACPD potentiation. Specificity of mGluR1 $\alpha$-stimulated insertion of NMDARs at
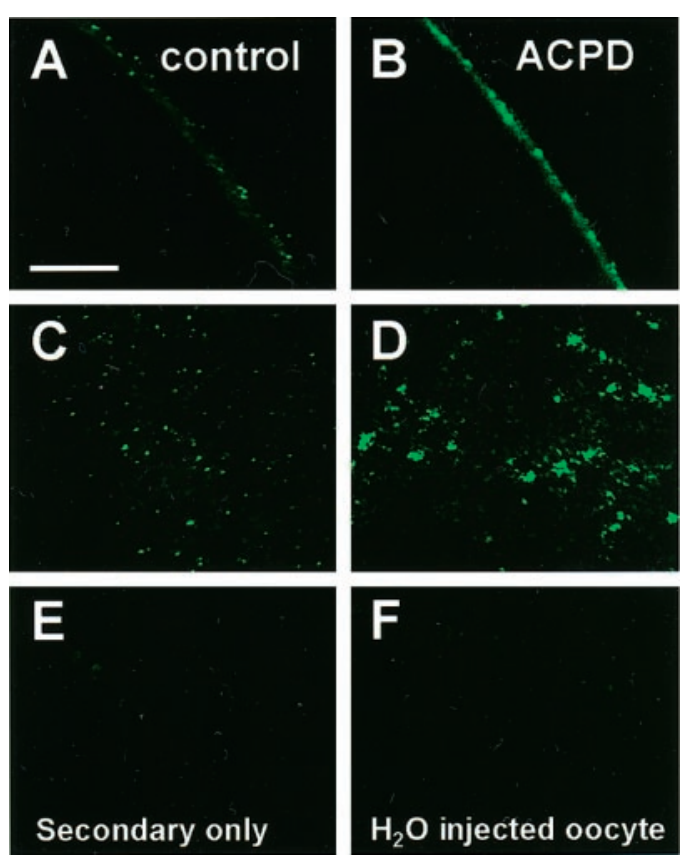

Figure 9. mGluR1 $\alpha$ increases NR1 surface immunofluorescence. Oocytes expressing $\mathrm{NR}_{100} / \mathrm{NR} 2 \mathrm{~A}$ receptors were incubated in external recording solution in the presence or absence of ACPD $(100 \mu \mathrm{M}, 10 \mathrm{~min})$ and subjected to immunocytochemistry. Immediately after incubation, intact oocytes were devitellinized mechanically, transferred to glass coverslips, and fixed with paraformaldehyde (4\%) and sucrose $(2 \%)$. To label surface NMDARs, fixed oocytes were incubated with NR1 antibody 54.1, followed by FITC-conjugated secondary antibody. NMDARs on the oocyte surface were then visualized using confocal microscopy. Surface fluorescence was expressed as the mean intensity of fluorescence per unit area. Shown are representative oocytes expressing NR1-4b/NR2A receptors from control $(A, B)$ and $\operatorname{ACPD}(C, D)$ treatment groups labeled by the extracellular epitope antibody. Control oocytes labeled by a secondary antibody in the absence of primary antibody $(E)$ and water-injected oocytes labeled as in $A-D$ showed negligible fluorescence $(F)$.

the cell surface is indicated by the observation that NR1/NR2A and NR1/NR2B but not NR1/NR2C receptors exhibit ACPDinduced potentiation. The present study is the first to examine biophysical mechanisms at the single-channel level in a system in which activation of group I mGluRs induces potentiation of NMDAR activity. We show that activation of mGluR $1 \alpha$ increases the number of functional NMDA channels at the cell surface, with no change in single-channel conductance, mean open duration, or open probability. Our study is also the first to demonstrate mGluR-mediated rapid trafficking of NMDARs in oocytes via a SNARE-dependent mechanism. A simple scenario is that activation of $\mathrm{mGluR} 1 \alpha$ regulates membrane fusion events of NMDAR-containing vesicles by activation of endogenous protein kinases, which in turn phosphorylate a protein involved in receptor trafficking. One potential target is SNAP-25, which can be directly phosphorylated in an activity-dependent manner (Shimazaki et al., 1996; Genoud et al., 1999). The intracellular signaling pathway linking mGluR1 activation with an increase in regulated exocytosis is, however, unknown, and association of SNAP-25 or its binding partners with NMDARs remains to be established.

Recent studies by our laboratory show that activation of PKC induces rapid delivery of NMDARs to the cell surface of oocytes and hippocampal neurons and an increase in the NMDA channel opening rate (Lan et al., 2001). Several findings indicate that the 
molecular mechanisms underlying mGluR1-mediated potentiation of NMDARs differ from those of PKC potentiation. First, ACPD regulates receptor trafficking in the absence of a significant effect on channel gating (although the present data cannot exclude a proportionately smaller change in the channel opening rate). Second, whereas the degree of TPA potentiation is markedly affected by NR1 splicing (Zheng et al., 1999), the degree of ACPD potentiation is affected only modestly by NR1 splicing, an effect that was not statistically significant in the present study. Third, whereas PKC-induced potentiation of NMDAR activity is observed in oocytes and dissociated hippocampal neurons, ACPD potentiation is observed in oocytes and in hippocampal slices but not in dissociated neurons, suggesting that the intracellular signaling pathway linking mGluR activation to NMDAR potentiation requires preservation of neuronal circuitry (P. J. Conn, personal communication).

Finally, group I mGluRs couple to diverse intracellular signaling pathways and potentiate NMDA EPSCs and NMDA-elicited currents by $\mathrm{PKC}$-independent signal transduction in some neuronal cell types and preparations and in expression systems. Electrophysiological studies of CA3 pyramidal neurons from rat hippocampal slice cultures indicate that synaptic activation of group I mGluRs (mGluR1) by mossy fiber stimulation evokes an EPSC by a G-protein-independent signaling pathway (Heuss et al., 1999). These studies show that an Src-family tyrosine kinase is an integral component in a signaling pathway that functionally links mGluR1 activation with a transient cationic conductance increase. Because NR1/NR2A NMDARs are functionally modified by tyrosine kinases such as Src (Wang and Salter, 1994), it is reasonable to propose that mGluR1 potentiates NMDA currents via activation of Src. Consistent with a role for tyrosine kinasedependent modulation of NMDAR activity, we recently reported that insulin promotes rapid exocytosis of NMDARs in Xenopus oocytes (Skeberdis et al., 2001a). Alternatively, group I mGluRs might signal via a membrane-delimited signaling pathway, as has been observed for mGluR-mediated inhibition of NMDAR activity in embryonic mouse cortical neurons (Yu et al., 1997).

The role of PKC-mediated signaling cascades in mGluR potentiation of NMDARs is, at best, controversial. mGluRmediated potentiation of NMDA EPSCs is reported to occur independently of PKC signaling in hippocampal (Harvey and Collingridge, 1993) and cerebellar slice preparations (Kinney and Slater, 1993), as is group I mGluR-mediated potentiation of NMDA currents in lamprey motoneurons (Krieger et al., 2000) and frog spinal cord neurons (Holohean et al., 1999). On the other hand, the intracellular pathway linking mGluRs to potentiation of NMDA responses appears to involve PKC in at least two preparations, although neither the mGluR nor NMDAR subtype or receptor class was identified in these preparations. PKC inhibitors block at least in part mGluR-mediated potentiation of NMDA EPSCs in hippocampal slice (Aniksztejn et al., 1992) and potentiation of NMDA currents in oocytes expressing rat brain mRNA (Kelso et al., 1992). Thus, multiple pathways might contribute to the group I mGluR-dependent regulation of NMDARs observed in the present study. This concept is supported by pharmacological studies; whereas mGluR-dependent potentiation of NMDARs is only partly blocked by selective PKC inhibitors, it is completely blocked by the broad-spectrum kinase inhibitor staurosporine (Skeberdis et al., 2001b).

\section{mGluR potentiation is via regulated exocytosis}

In the present study, ACPD potentiation of NMDA-elicited currents was inhibited by $\sim 50 \%$ injection of BoNT A and nearly completely abolished by expression of SNAP-25( $\Delta 20)$ (Figs. 5, 6). These findings provide important new evidence for a mechanism involving regulated exocytosis of NMDARs to the cell surface of the oocyte. Inhibition of exocytosis by BoNT A is incomplete in a number of other systems, including exocytosis of $I_{\text {soc }}$ channels (Yao et al., 1999) and NMDARs in Xenopus oocytes (Lan et al., 2001). The action of BoNT A on regulated exocytosis of NMDARs was relatively specific in that (1) ACPD-induced insertion of new channel molecules was not inhibited by BoNT B or $\mathrm{E}$; and (2) constitutive expression of NMDARs and endogenous $\mathrm{Ca}^{2+}$-activated $\mathrm{Cl}^{-}$channels (Yao et al., 1999; our unpublished observations) and transfected epithelial $\mathrm{Na}^{+}$channels (Yao et al., 1999) in oocytes is not reduced by BoNT A.

\section{Structural basis of localization of group I mGluRs and NMDARs}

Immunogold studies reveal a highly ordered arrangement of group I mGluRs and NMDARs at the postsynaptic membrane of CA1 synapses and indicate that the two classes of receptors are concentrated in microdomains in close proximity to one another (Baude et al., 1993; Lujan et al., 1996; Lujan et al., 1997; Shigemoto et al., 1997). Studies involving the yeast two-hybrid system and immunoprecipitation suggest that mGluR $1 \alpha$ and mGluR5 may be cross-linked to NMDARs at synapses. The C-terminal tails of mGluR1 and mGluR5 contain a recognition sequence for binding by members of the Homer family of anchoring proteins (Tu et al., 1998). Homer proteins, in turn, link via Shank and PSD to each other and to $\mathrm{IP}_{3}$ receptors, NMDARs, and AMPARs (Tu et al., 1999). Thus, a scaffolding structure consisting of Homer and Shank may directly connect group I mGluRs to NMDARs, thereby providing strategic positioning for regulation of NMDARs by mGluRs at hippocampal synapses.

\section{Physiological significance of mGluR1 potentiation of NMDARs}

The physiological relevance of mGluR 1 actions is underscored by observations that activation of group I mGluRs induces potentiation of NMDA EPSCs in rat hippocampal (Aniksztejn et al., 1992; Challiss et al., 1994), striatal (Pisani et al., 1997), and subthalamic nucleus (Awad et al., 2000) slices and potentiation of NMDA currents in lamprey motoneurons (Krieger et al., 2000) and frog spinal cord neurons (Holohean et al., 1999). Turnover and biotinylation studies of cerebellar granule neurons indicate a large pool of NR1 subunits ( $\sim 60 \%$ total NR1) in the cytoplasm of dendritic shafts and spines, where they are poised for rapid assembly with NR2 subunits and insertion at synaptic sites (Huh and Wenthold, 1999). Rapid trafficking of AMPARs between the plasma membrane and an intracellular compartment in response to synaptic activity (Nishimune et al., 1998; Osten et al., 1998; Song et al., 1998) and synaptic plasticity (Carroll et al., 1999) is thought to represent recycling.

Findings from the present study suggest a mechanism whereby group I mGluRs can augment the number of synaptic NMDARs, thereby modulating neuronal excitability and lowering the threshold for LTP and long-term depression. Moreover, activation of NMDARs potentiates mGluR5 activity (Challiss et al., 1994; Luthi et al., 1994; Alagarsamy et al., 1999); mechanisms implicated in this potentiation include a rise in intracellular $\mathrm{Ca}^{2+}$, activation of calcineurin, and inhibition of PKC (De Blasi et al., 
2001). Thus, positive interactions between mGluRs and NMDARs may be reciprocal in nature and important to NMDAR-dependent LTP. The present study extends earlier studies by providing insight into the biophysical and molecular mechanisms underlying mGluR1-mediated regulation of NMDARs in a pure population of receptors. Insertion and retrieval of NMDARs to and from the plasma membrane are likely to be common and powerful mechanisms for regulating excitatory synaptic transmission.

\section{REFERENCES}

Aiba A, Chen C, Herrup K, Rosenmund C, Stevens CF, Tonegawa S (1994a) Reduced hippocampal long-term potentiation and contextspecific deficit in associative learning in mGluR1 mutant mice. Cell 79:365-375.

Aiba A, Kano M, Chen C, Stanton ME, Fox GD, Herrup K, Zwingman TA, Tonegawa S (1994b) Deficient cerebellar long-term depression and impaired motor learning in mGluR1 mutant mice. Cell 79:377-388.

Akabas MH, Stauffer DA, Xu M, Karlin A (1992) Acetylcholine receptor channel structure probed in cysteine-substitution mutants. Science 258:307-310.

Alagarsamy S, Marino MJ, Rouse ST, Gereau RW4, Heinemann SF, Conn PJ (1999) Activation of NMDA receptors reverses desensitization of mGluR5 in native and recombinant systems. Nat Neurosci $2: 234-240$

Aniksztejn L, Otani S, Ben-Ari Y (1992) Quisqualate metabotropic receptors modulate NMDA currents and facilitate induction of long-term potentiation through protein kinase C. Eur J Neurosci 4:500-505.

Aramori I, Nakanishi S (1992) Signal transduction and pharmacological characteristics of a metabotropic glutamate receptor, mGluR1, in transfected CHO cells. Neuron 8:757-765.

Araneda RC, Lan JY, Zheng X, Zukin RS, Bennett MV (1999) Spermine and arcaine block and permeate $N$-methyl-D-aspartate receptor channels. Biophys J 76:2899-2911.

Awad H, Hubert GW, Smith Y, Levey AI, Conn PJ (2000) Activation of metabotropic glutamate receptor 5 has direct excitatory effects and potentiates NMDA receptor currents in neurons of the subthalamic nucleus. J Neurosci 20:7871-7879.

Baude A, Nusser Z, Roberts JD, Mulvihill E, McIlhinney RA, Somogyi P (1993) The metabotropic glutamate receptor (mGluR1 alpha) is concentrated at perisynaptic membrane of neuronal subpopulations as detected by immunogold reaction. Neuron 11:771-787.

Bennett MK, Scheller RH (1993) The molecular machinery for secretion is conserved from yeast to neurons. Proc Natl Acad Sci USA 90:2559-2563.

Bordi F (1996) Reduced long-term potentiation in the dentate gyrus of mGlu1 receptor-mutant mice in vivo. Eur J Pharmacol 301:R15-R16.

Carroll RC, Lissin DV, von Zastrow M, Nicoll RA, Malenka RC (1999) Rapid redistribution of glutamate receptors contributes to long-term depression in hippocampal cultures. Nat Neurosci 2:454-460.

Challiss RAJ, Mistry R, Gray DW, Nahorski SR (1994) Modulatory effects of NMDA on phosphoinositide responses evoked by the metabotropic glutamate receptor agonist $1 S, 3 R$-ACPD in neonatal rat cerebral cortex. Br J Pharmacol 112:231-239.

Chen N, Luo T, Raymond LA (1999) Subtype-dependence of NMDA receptor channel open probability. J Neurosci 19:6844-6854.

Conn PJ, Pin JP (1997) Pharmacology and functions of metabotropic glutamate receptors. Annu Rev Pharmacol Toxicol 37:205-237.

Conquet F, Bashir ZI, Davies CH, Daniel H, Ferraguti F, Bordi F, Franz-Bacon K, Reggiani A, Matarese V, Conde F (1994) Motor deficit and impairment of synaptic plasticity in mice lacking mGluR1. Nature 372:237-243.

De Blasi A, Conn PJ, Pin J, Nicoletti F (2001) Molecular determinants of metabotropic glutamate receptor signaling. Trends Pharmacol Sci 22:114-120.

Durand GM, Gregor P, Zheng X, Bennett MV, Uhl GR, Zukin RS (1992) Cloning of an apparent splice variant of the rat $N$-methyl-Daspartate receptor NMDAR1 with altered sensitivity to polyamines and activators of protein kinase C. Proc Natl Acad Sci USA 89:9359-9363.

Gazzaley AH, Weiland NG, McEwen BS, Morrison JH (1996) Differential regulation of NMDAR1 mRNA and protein by estradiol in the rat hippocampus. J Neurosci 16:6830-6838.

Genoud S, Pralong W, Riederer BM, Eder L, Catsicas S, Muller D (1999) Activity-dependent phosphorylation of SNAP-25 in hippocampal organotypic cultures. J Neurochem 72:1699-1706.

Harvey J, Collingridge G (1993) Signal transduction pathways involved in the acute potentiation of NMDA responses by $1 S, 3 R$-ACPD in rat hippocampal slices. Br J Pharmacol 109:1085-1090.

Heuss C, Scanziani M, Gahwiler BH, Gerber U (1999) G-proteinindependent signaling mediated by metabotropic glutamate receptors. Nat Neurosci 2:1070-1077.
Hollmann M, Maron C, Heinemann S (1994) N-glycosylation site tagging suggests a three transmembrane domain topology for the glutamate receptor GluR1. Neuron 13:1331-1343.

Holohean AM, Hackman JC, Davidoff RA (1999) Mechanisms involved in the metabotropic glutamate receptor-enhancement of NMDAmediated motoneurone responses in frog spinal cord. Br J Pharmacol 126:333-341.

Huh KH, Wenthold RJ (1999) Turnover analysis of glutamate receptors identifies a rapidly degraded pool of the $N$-methyl-D-aspartate receptor subunit, NR1, in cultured cerebellar granule cells. J Biol Chem 274:151-157.

Jahr CE (1992) High probability opening of NMDA receptor channels by $L$-glutamate. Science 255:470-472.

Joly C, Gomeza J, Brabet I, Curry K, Bockaert J, Pin JP (1995) Molecular, functional, and pharmacological characterization of the metabotropic glutamate receptor type 5 splice variants: comparison with mGluR1. J Neurosci 15:3970-3981.

Kaczmarek L, Kossut M, Skangiel-Kramska J (1997) Glutamate receptors in cortical plasticity: molecular and cellular biology. Physiol Rev 77:217-255

Kelso SR, Nelson TE, Leonard JP (1992) Protein kinase C-mediated enhancement of NMDA currents by metabotropic glutamate receptors in Xenopus oocytes. J Physiol (Lond) 449:705-718.

Kinney GA, Slater NT (1993) Potentiation of NMDA receptormediated transmission in turtle cerebellar granule cells by activation of metabotropic glutamate receptors. J Neurophysiol 69:585-594.

Krieger P, Hellgren-Kotaleski J, Kettunen P, El Manira AJ (2000) Interaction between metabotropic and ionotropic glutamate receptors regulates neuronal network activity. J Neurosci 20:5382-5391.

Lan JY, Skeberdis VA, Jover T, Grooms SY, Lin Y, Araneda RC, Zheng X, Bennett MV, Zukin RS (2001) Protein kinase C modulates NMDA receptor trafficking and gating. Nat Neurosci 4:382-390.

Legendre P, Rosenmund C, Westbrook GL (1993) Inactivation of NMDA channels in cultured hippocampal neurons by intracellular calcium. J Neurosci 13:674-684.

Leonard JP, Kelso SR (1990) Apparent desensitization of NMDA responses in Xenopus oocytes involves calcium-dependent chloride current. Neuron 4:53-60.

Lu YM, Jia Z, Janus C, Henderson JT, Gerlai R, Wojtowicz JM, Roder JC (1997) Mice lacking metabotropic glutamate receptor 5 show impaired learning and reduced CA1 long-term potentiation (LTP) but normal CA3 LTP. J Neurosci 17:5196-5205.

Lujan R, Nusser Z, Roberts JD, Shigemoto R, Somogyi P (1996) Perisynaptic location of metabotropic glutamate receptors mGluR1 and mGluR5 on dendrites and dendritic spines in the rat hippocampus. Eur J Neurosci 8:1488-1500.

Lujan R, Roberts JD, Shigemoto R, Ohishi H, Somogyi P (1997) Differential plasma membrane distribution of metabotropic glutamate receptors mGluR1 alpha, mGluR2 and mGluR5, relative to neurotransmitter release sites. J Chem Neuroanat 13:219-241.

Luthi A, Gahwiler BH, Gerber U (1994) Potentiation of a metabotropoic glutamatergic response following NMDA receptor activation in rat hippocampus. Pflügers Arch 427:197-202.

Montecucco C, Schiavo G (1995) Structure and function of tetanus and botulinum neurotoxins. Q Rev Biophys 28:423-472.

Mori H, Yamakura T, Masaki H, Mishina M (1993) Involvement of the carboxyl-terminal region in modulation by TPA of the NMDA receptor channel. NeuroReport 4:519-522.

Nicoletti F, Bruno V, Catania MV, Battaglia G, Copani A, Barbagallo G, Cena V, Sanchez-Prieto J, Spano PF, Pizzi M (1999) Group-I metabotropic glutamate receptors: hypotheses to explain their dual role in neurotoxicity and neuroprotection. Neuropharmacology 38:1477-1484.

Nishimune A, Isaac JT, Molnar E, Noel J, Nash SR, Tagaya M, Collingridge GL, Nakanishi S, Henley JM (1998) NSF binding to GluR2 regulates synaptic transmission. Neuron 21:87-97.

Okabe S, Miwa A, Okado H (1999) Alternative splicing of the C-terminal domain regulates cell surface expression of the NMDA receptor NR1 subunit. J Neurosci 19:7781-7792.

Opitz T, Richter P, Reymann KG (1994) The metabotropic glutamate receptor antagonist (+)-alpha-methyl-4-carboxyphenylglycine protects hippocampal CA1 neurons of the rat from in vitro hypoxia/hypoglycemia. Neuropharmacology 33:715-717.

Osten P, Srivastava S, Inman GJ, Vilim FS, Khatri L, Lee LM, States BA, Einheber S, Milner TA, Hanson PI, Ziff EB (1998) The AMPA receptor GluR2 C terminus can mediate a reversible, ATP-dependent interaction with NSF and alpha- and beta-SNAPs. Neuron 21:99-110.

Pin JP, Duvoisin R (1995) The metabotropic glutamate receptors: structure and functions. Neuropharmacology 34:1-26.

Pisani A, Calabresi P, Centonze D, Bernardi G (1997) Enhancement of NMDA responses by group I metabotropic glutamate receptor activation in striatal neurones. Br J Pharmacol 120:1007-1014.

Rosenmund C, Feltz A, Westbrook GL (1995) Synaptic NMDA receptor channels have a low open probability. J Neurosci 15:2788-2795.

Saugstad JA, Segerson TP, Westbrook GL (1996) Metabotropic gluta- 
mate receptors activate G-protein-coupled inwardly rectifying potassium channels in Xenopus oocytes. J Neurosci 16:5979-5985.

Shigemoto R, Kinoshita A, Wada E, Nomura S, Ohishi H, Takada M, Flor PJ, Neki A, Abe T, Nakanishi S, Mizuno N (1997) Differential presynaptic localization of metabotropic glutamate receptor subtypes in the rat hippocampus. J Neurosci 17:7503-7522.

Shimazaki Y, Nishiki T, Omori A, Sekiguchi M, Kamata Y, Kozaki S, Takahashi M (1996) Phosphorylation of 25-kDa synaptosomeassociated protein. Possible involvement in protein kinase $\mathrm{C}$-mediated regulation of neurotransmitter release. J Biol Chem 271:14548-14553.

Skeberdis VA, Lan JY, Opitz T, Zheng X, Bennett MVL, Zukin RS (2001a) mGluR1-mediated potentiation of NMDA receptors involves a rise in intracellular calcium and activation of protein kinase $\mathrm{C}$. Neuropharmacology 40:856-865.

Skeberdis VA, Lan J, Zheng X, Zukin RS, Bennett MV (2001b) Insulin promotes rapid delivery of $N$-methyl-D-aspartate receptors to the cell surface by exocytosis. Proc Natl Acad Sci USA 98:3561-3566.

Song I, Kamboj S, Xia J, Dong H, Liao D, Huganir RL (1998) Interaction of the $N$-ethylmaleimide-sensitive factor with AMPA receptors. Neuron 21:393-400.

Tu JC, Xiao B, Yuan JP, Lanahan AA, Leoffert K, Li M, Linden DJ, Worley PF (1998) Homer binds a novel proline-rich motif and links group 1 metabotropic glutamate receptors with IP3 receptors. Neuron 21:717-726.

Tu JC, Xiao B, Naisbitt S, Yuan JP, Petralia RS, Brakeman P, Doan A, Aakalu VK, Lanahan AA, Sheng M, Worley PF (1999) Coupling of
mGluR/Homer and PSD-95 complexes by the Shank family of postsynaptic density proteins. Neuron 23:583-592.

Wang YT, Salter MW (1994) Regulation of NMDA receptors by tyrosine kinases and phosphatases. Nature 369:233-235.

Wolf ME (1998) The role of excitatory amino acids in behavioral sensitization to psychomotor stimulants. Prog Neurobiol 54:679-720.

Yao Y, Ferrer-Montiel AV, Montal M, Tsien RY (1999) Activation of store-operated $\mathrm{Ca}^{2+}$ current in Xenopus oocytes requires SNAP-25 but not a diffusible messenger. Cell 98:475-485.

Yu SP, Sensi SL, Canzoniero LM, Buisson A, Choi DW (1997) Membrane-delimited modulation of NMDA currents by metabotropic glutamate receptor subtypes $1 / 5$ in cultured mouse cortical neurons. J Physiol (Lond) 499:721-732.

Zampighi GA, Loo DD, Kreman M, Eskandari S, Wright EM (1999) Functional and morphological correlates of connexin 50 expressed in Xenopus laevis oocytes. J Gen Physiol 113:507-524.

Zheng X, Zhang L, Wang AP, Bennett MV, Zukin RS (1997) $\mathrm{Ca}^{2+}$ influx amplifies protein kinase $\mathrm{C}$ potentiation of recombinant NMDA receptors. J Neurosci 17:8676-8686.

Zheng X, Zhang L, Wang AP, Bennett MV, Zukin RS (1999) Protein kinase $C$ potentiation of $N$-methyl-D-aspartate receptor activity is not mediated by phosphorylation of $N$-methyl-D-aspartate receptor subunits. Proc Natl Acad Sci USA 96:15262-15267.

Zukin RS, Bennett MV (1995) Alternatively spliced isoforms of the NMDARI receptor subunit. Trends Neurosci [erratum (1995) 18:441] 18:306-313. 